\title{
Strategi Pembelajaran Shalat Oleh Guru Pendidikan Agama Islam terhadap Anak Tunadaksa di SDLB Negeri Pangkalpinang
}

\author{
Ruzaipah 1*, Muhammad Munir 2, Agus Ma'sum Aljauhari ${ }^{3}$ \\ ${ }^{1}$ Fakultas Syariah dan Hukum Universitas Islam Negeri Sunan Kalijaga \\ 2 Fakultas Syariah dan Hukum Universitas Islam Negeri Sunan Kalijaga \\ 3 Fakultas Syariah dan Hukum Universitas Islam Negeri Sunan Kalijaga
}

\begin{abstract}
:
Keywords:

Learning Strategy,

Shalat,

Disabled Children

*Correspondence Address: muhammadruzaipah15@gmail .com

The focus of the study is on the Islamic religious education strategy for disabled children. Disabled children are those with orthopedic disorders or disorders of normal function in bones, muscles, and joints because of congenital birth, illness, or accident. So that any movement or walking is necessary. Physical disability of disabled children causes them to go through obstacles to performing the prayers. With disabilities different from other children, the education teachers of Islam guide disabled children in performing prayers. The study aims to describe the learning strategy and to provide more information about the weaknesses and strengths of the learning strategy used by the Islamic religious education teacher. The study uses descriptive types of qualitative research. Data is obtained through methods of interviews, observation, and documentation. Research shows that the strategy used by the Islamic education teacher in The State SDLB of Pangkalpinang is a factually, contextual, and cooperative learning strategy. The weaknesses of these three strategies are that they cannot be used to students with hearing problems, teachers must be more intense in their guidance, and implementation requires considerable time. The advantage is that teachers can control the sequence and the broadness of the material, the study is more fun and less boring, and communicate with others.
\end{abstract}

\section{PENDAHULUAN}

Guru memegang peranan penting
dalam peningkatan kualitas
pembelajaran, baik kualitas proses
maupun kualitas lulusan. Tugas utama
guru bukanlah mengajar dalam arti
menyampaikan konsep, teori, dan fakta
akademik semata kepada peserta didik,
tetapi tugas guru juga membantu
kesulitan belajar peserta didik dalam

melakukan proses pematangan kualitas dirinya. Upaya itu dilakukan melalui proses pengajaran, bimbingan, penyuluhan, penerangan, latihan, atau pendekatan lainnya yang memungkinkan peserta didik melakukan proses pematangan kualitas diri dan kepribadian unggul. Seorang guru harus mampu memerankan dirinya dalam menyajikan materi. ${ }^{1}$

1 Dedi Mulyasana, Pendidikan Bermutu dan Berbudaya Saing, (Bandung: PT Remaja Rosdakarya Offset, 2011), 45. 
Menjadi seorang guru merupakan tugas mulia karena bisa membimbing anak didik dari belum bisa menjadi bisa, dari belum tahu menjadi tahu, dan dari belum sukses menjadi sukses, apalagi menjadi guru ABK (anak berkebutuhan khusus) yang diartikan sebagai anakanak yang memiliki karakter berbeda, baik secara fisik, emosi, ataupun mental dengan anak-anak lain seusianya. Karakteristik berbeda ini tidak selalu mengacu pada ketidak mampuan fisik, emosi, ataupun mental mereka, tetapi terlebih pada perbedaannya. Karena anak yang kecerdasannya di atas ratarata pun termasuk ke dalam $A B K$ sebab membutuhkan stimulasi tepat agar terarah padahal yang baik dan maksimal. Stimulasi tersebut terutama berasal dari kedua orang tua, keluarga dan kemudian pendidikannya. ${ }^{2}$

Berbagai karakteristik khusus yang membedakannya dengan anak lain, perbedaan yang mencolok terjadi pada emosional para $\mathrm{ABK}{ }^{3}$ Perbedaan pada pengelolaan emosi ini terlebih karena mereka merasa ada yang berbeda dengan dirinya dibandingkan anak-anak lain. Kebutuhan akan perhatian dan penerimaan diri yang lemah membuat $A B K$ sering sulit untuk mengendalikan emosinya. Bukan hanya terjadi pada $\mathrm{ABK}$ dengan karakteristik psikis tertentu seperti Autis atau ADHD, tetapi terjadi hampir pada setiap ABK. ${ }^{4}$

Kajian terdahulu terkait strategi guru Pendidikan Agama Islam bagi anak

${ }^{2}$ Afin Murtie, Ensikopedi Anak

Berkebutuhan Khusus, (Jogyakarta: Redaksi maxima, 2016), 8.

3 Penyelenggaraan pendidikan untuk ABK memang dikhususkan, seperti yang tercantum pada Undang-Undang Nomor 20 Tahun 2003 tentang Sistem Pendidikan Nasional terutama pasal 5 ayat (2) disebutkan bahwa warga negara yang memiliki kelainan fisik, emosional, mental, intelektual dan/atau sosial berhak memperoleh tunadaksa adalah penelitian yang dilakukan oleh Nurdin, di mana hasil penelitiannya menyatakan bahwa strategi pembelajarannya disesuaikan dengan kondisi ketunaan mereka masing-masing. Strategi tersebut antara lain strategi pembelajaran ekspositori dan strategi komunikasi yang efektif. Kemudian pelaksanaannya terlaksana dengan baik walau terdapat beberapa kendala dalam pelaksanaan pembelajarannya seperti, pengembangan materi pembelajaran yang efektif, pendekatan, strategi, metode, teknik, media, kurikulum dan evaluasi akhir bagi anak tunadaksa dengan menggunakan pendekatan klasikal individu dan pendekatan individu. Selain itu dalam pelaksanaan pembelajarannya terdapat beberapa kendala lain, diantaranya ialah: masih berkurangnya buku penunjang pembelajaran PAI khusus untuk anak tunadaksa, masih kurangnya pendanaan, metode pembelajaran yang digunakan guru masih monoton, proses pembelajaran memerlukan waktu yang terlalu panjang dan tingkat kesadaran masyarakat umum dan keluarga penyandang anak tunadaksa tentang arti pentingnya pendidikan masih kurang. Selanjutnya upaya yang ditempuh antara lain: penyediaan sarana dan prasarana yang lengkap, penyediaan media pembelajaran yang lengkap, pendanaan dan pengadaan buku penunjang yang lengkap,

pendidikan khusus dan juga pada pasal 32 ayat (1) bahwa pendidikan khusus merupakan pendidikan bagi peserta yang memiliki tingkat kesulitan dalam mengikuti proses pembelajaran karena karakterisitik fisik, emosional, mental, sosial, dan/atau memiliki potensi kecerdasan dan bakat istimewa yang berbeda dengan anakanak lainnya. Lihat Undang-Undang Nomor 20 Tahun 2003 tentang Sistem Pendidikan Nasional terutama pasal 5 ayat (2)

${ }^{4}$ Ibid...,9. 
pengembangan kegiatan akademik anak tunadaksa, pengembangan kegiatan akademik guru melalui berbagai pelatihan dan penataran, mengevaluasi kinerja guru dan mewujudkan kerja sama yang harmonis dengan pihakpihak terkait. ${ }^{5}$

Penanaman nilai-nilai Agama Islam merupakan hal yang sangat penting, terutama dalam menghadapi era globalisasi. Penanaman nilai-nilai tersebut penting untuk semua anak muslim baik anak berkebutuhan umum maupun anak berkebutuhan khusus (ABK), khususnya anak penyandang tunadaksa. Untuk menunjukkan pentingnya nilai-nilai agama dalam kehidupan manusia, Allah SWT mengutus Nabi Muhammad SAW dan menjadikannya suri tauladan yang baik bagi umat manusia. Penanaman nilainilai Pendidikan Agama Islam juga selalu ditanamkan dan diberikan kepada murid tunadaksa SDLB Negeri Pangkalpinang, diantaranya adalah pembelajaran shalat.

Menurut informasi yang didapat dari Guru Pendidikan Agama Islam Ibu Isnayani, Terdapat 5 anak tunadaksa yang mempunyai karakteristik dan usia yang berbeda-beda. Mulai dari tidak bisa berjalan, tidak bisa berbicara, sehingga guru mengalami kesulitan dalam memberikan materi pembelajaran. Apalagi dalam materi pembelajaran shalat yang berhubungan dengan gerak dan suara. Hal ini tentu menjadi tantangan tersendiri bagi guru yang mengajar di $\mathrm{SLB}^{6}$ Negeri

5 Nurdin, Strategi Pembelajaran Pendidikan Agama Islam Bagi Anak Tunadaksa Di Sekolah Dasar Luar Biasa (SDLB) Negeri Kota Juang Kabupaten Bireuen, Tesis, Program Pasca Sarjana Prodi Pendidikan Islam Konsentrasi Pendidikan Agama Islam IAIN Sumatra Utara, (online) available: http://repository.uinsu.ac.ai/2952/1/tesis\%20N urdin\%20.pdf, diakses pada tanggal 15 November 2018.
Pangkalpinang, terutama Guru Pendidikan Agama Islam dalam pembelajaran Shalat.?

Persoalan ini sangat menarik untuk diteliti karena terdapat berbagai macam karakteristik anak tunadaksa yang memiliki kelainan atau gangguan fisik yang berkaiatan dengan tulang, otot, sendi dan sistem persyarafan dan memerlukan pelayanan khusus. Oleh karena itu, tulisan ini akan membahas strategi yang digunakan guru Pendidikan Agama Islam dalam pembelajaran shalat, sekaligus membahas kelemahan dan kelebihan penggunaan starategi pembelajaran shalat oleh guru Pendidikan Agama Islam pada anak Tunadaksa di SDLB Negeri Pangkalpinang.

\section{LANDASAN TEORI}

\section{Strategi Pembelajaran}

Pada umumnya istilah strategi banyak digunakan oleh bidang-bidang ilmu lain, termasuk bidang militer maupun bidang pendidikan. ${ }^{8}$ Strategi diartikan sebagai petunjuk umum dimana suatu organisasi merencanakan untuk mencapai tujuannya. Menurut Veithzal Rivai dan Andria Permata Veithzal, strategi merupakan upaya untuk menyusun target (sasaran), program, dan proyek untuk tercapainya tujuan-tujuan serta tugas pokok perencanaan. Strategi disusun berdasarkan premies dan tujuan yang telah ditetapkan. ${ }^{9}$

6 Sekolah Luar Biasa

7 Isnayani Guru Pendidikan Agama Islam, Wawancara, pada tanggal 14 Maret 2019.

8 Abu Ahmadi dan Joko Tri Presetya, Strategi Belajar Mengajar, (Bandung: Pustaka Setia, 2015), 11.

${ }^{9}$ Kenichi Ohmae dikutip oleh Veithzal Rivai dan Andria Permata Veithzal, Islamic Financial Management, (Jakarta: PT Raja Grafindo Persada, 2010), 239. 
Dalam hal ini strategi pembelajaran adalah suatu rencana tindakan (rangkaian tindakan) yang dilakukan seseorang agar tujuan yang ditentukan dapat tercapai dengan baik, termasuk penggunaan metode dan pemanfaatan berbagai sumber daya/kekuatan dalam proses belajar mengajar. ${ }^{10}$ Adapun tujuan strategi menurut Nana Syaodih yang dikutip oleh Muhammad ialah sebagai berikut:

a. Memudahkan optimalisasi kegiatan belajar mengajar sehingga dapat melakukan kegiatan secara lebih mandiri.

b. Memudahkan guru memilih dan menyusun bahan ajar

c. Membantu dan memudahkan guru menentukan kegiatan belajar dan media pembelajaran.

d. Memudahkan guru mengadakan penilaian. ${ }^{11}$

Berdasarkan pemaparan di atas, strategi pembelajaran bertujuan untuk mempermudah proses kegiatan belajar mengajar sehingga pembelajaran yang dinginkan tercapai secara efektif dan efesien.

\section{Jenis-Jenis Strategi Pembelajaran}

Untuk melaksanakan strategi tertentu diperlukan seperangkat metode pengajaran sebagaimana berikut:

1. Strategi Pembelajaran Kreatif Strategi pembelajaran interaktif merujuk kepada bentuk diskusi dan saling berbagi di anatara peserta didik. Strategi pembelajaran interaktif

\footnotetext{
10 Hamzah B Uno, Model PembelajaranMenciptakan Proses Belajar Mengajar yang Kreatif dan Efektif, (Jakarta: Bumi Aksara, 2010), 1.

11 Muhammad Rohan dan Sofan Amir, Strategi dan Desain Pengembangan Sistem
}

dikembangkan dalam rentang pengelompokan dan metodemetode interaktif. Di dalamnya terdapat bentuk-bentuk diskusi kelas, diskusi kelompok kecil atau pengerjaan tugas berkelompok, dan kerja sama siswa secara berpasangan. ${ }^{12}$

2. Strategi Pembelajaran Tidak Langsung

Strategi ini memperlihatkan bentuk keterlibatan siswa yang tinggi dalam melakukan observasi, penyelidikan, penggambaran inferensi berdasarkan data, atau pembentukan hipotesis. Dalam pembelajaran tidak langsung, peran guru beralih dari penceramah menjadi fasilitator, pendukung dan sumber personal. Guru merancang lingkungan belajar, memberikan kesempatan siswa untuk terlibat, dan jika memungkinkan memberikan umpan balik kepada siswa ketika mereka melakukan inkuiri. Strategi ini juga mensyaratkan digunakannya bahan-bahan cetak, non cetak, dari sumbersumber manusia. ${ }^{13}$

3. Strategi Pembelajaran Individualisasi

Strategi ini merupakan salah satu strategi pembelajaran yang dilakukan oleh peserta didik secara mandiri. Kecepatan, kelambatan dan keberhasilan pembelajaran peserta didik sangat ditentukan oleh

Pembelajaran, (Jakarta: Prestasi Pustaka Publisher, 2013), 109.

12 Abdul Majid, Strategi Pembelajaran,

(Bandung:PT Remaja Rosdakarya, 2015), 11.

13 Ibid..., 11. 
kemampuan individu peserta didik. Bahan pelajaran serta bahan untuk dipelajari didesain untuk belajar sendiri. Contoh dari strategi ini adalah belajar melalui modul, atau belajar melalui kaset audio. ${ }^{14}$

\section{Anak Tunadaksa}

Istilah tunadaksa berasal dari kata "tuna yang berarti rugi atau kurang dan daksa yang berarti tubuh."Tunadaksa adalah anak yang memiliki anggota tubuh tidak sempurna, Anak tunadaksa sering disebut cacat fisik. Anak tunadaksa adalah ketidakmampuan anggota tubuh untuk melaksanakan fungsinya disebabkan oleh berkurangnya kemampuan anggota tubuh untuk melaksanakan fungsinya secara normal, sebagai akibat bawaan, luka penyakit, atau pertumbuhan yang tidak sempurna sehingga untuk kepentingan pembelajarannya perlu layanan secara khusus. ${ }^{15}$

Maka dapat disimpulkan bahwa, Tunadaksa merupakan suatu keadaan atau bentuk ketidakmampuan anggota tubuh untuk melaksanakan fungsinya disebabkan oleh berkurangnya kemampuan anggota tubuh untuk melakanankan fungsi secara normal akibat penyakit, kecelakaan, luka, atau pertumbuhan yang tidak sempurna sehingga untuk kepentingan pendidikannya memerlukan pelayanan dan cara-cara secara khusus.

\section{Strategi Pembelajaran dan Anak Tunadaksa}

Adapun strategi pembelajaran untuk anak Tunadaksa ialah sebagai berikut:

14 Anisa Zein, "Strategi Pembelajaran Pendidikan Agama Islam Pada Anak Berkebutuhan Khusus (ABK) Tunarungu di SLB ABC Taman Pendidikan Islam Medan", Skripsi Fakultas Ilmu Tarbiyah dan Keguruan UIN Sumatera Utara, Medan, 2018, 28-29.
1. Strategi Pembelajaran Ekspositori

Strategi ini Terdapat beberapa karakteristik strategi pembelajaran expositori. Pertama, strategi pembelajaran expositori dilakukan dengan cara menyampaikan materi pelajaran materi pelajaran secara verbal, bertutur secara lisan merupakan alat pertama dalam melakukan strategi ini. Oleh karena itu orang mengidentikkannya dengan ceramah. Kedua biasanya materi pelajaran yang disampaikan adalah materi yang sudah jadi, seperti data atau fakta, konsepkonsep tertentu yang harus dihapal sehingga tidak menuntut siswa untuk berfikir ulang. Ketiga tujuan utama pembelajaran adalah penguasaan materi pelajaran itu sendiri. Artinya ketika proses pembelajaran berakhir siswa diharapakan memahaminya dengan benar dengan cara mengungkapkan kembali materi yang telah dijelaskan. ${ }^{16}$ Adapun kelemahannya strategi pembelajaran ini hanya dilakukan pada siswa yang memiliki kemampuan mendengar dan menyimak secara baik. ${ }^{17}$ Sedangkan kelebihannya strategi pembelajaran ekspositori guru bisa mengontrol urutan dan keluasan materi pembelajaran, ia dapat mengetahui sampai sejauh

${ }^{15} J a t i$ Rinakri Atmaja, Pendidikan Dan Bimbingan Anak Berkebutuhan Khusus, (Bandung: PT Remaja Rosdakarya, 2018), 127.

16 Ibid..., 179.

17 Ibid.., 191 
mana siswa menguasai bahan pelajaran yang disampaikan.

2. Strategi Kontekstual (CTL)

Strategi ini menekankan kepada proses keterlibatan siswa secara penuh untuk menemukan materi yang dipelajari dan menghubungkannya dengan situasi kehidupan nyata sehingga mendorong siswa untuk menerapakannya dalam kehidupan Pembelajaran mereka. adalah belajar dalam rangka memperoleh dan menambah pengetahuan baru. Artinya pengetahuan yang diperoleh bukan untuk dihafal tetapi untuk dipahami dan diyakini, sehingga pengetahuan dan pengalaman yang diperolehnya harus dapat diaplikasikan dalam kehidupan peserta didik supaya tampak perubahan perilaku. ${ }^{18}$ Adapun kelemahannya guru lebih intensif dalam membimbing, karena dalam startegi ini guru tidak lagi berperan sebagai pusat informasi, melainkan guru adalah pembimbing siswa agar mereka dapat belajar sesuai dengan tahap perkembangannya. Sedangkan kelebihannya pembelajaran lebih menyenangkan dan tidak membosankan serta terbentuk sikap kerja sama yang baik antarindividu maupun kelompok. ${ }^{19}$

18 Ibid..., 255-256.

19 Muhammad Haqiqi, Menrisal, dkk, "Pengaruh Mode Pembelajaran Kontekstual Tacing and Learning terhadap Hasil BelajarTeknologi Informasi dan Komunikasi", Fakultas Keguruaan Il mu Pendidikan, Universitas Putra Indonesia Padang, (online)
3. Strategi

Pembelajaran

Kooperatif

Pembelajaran

kooperatif merupakan rangkaian kegiatan belajar yang dilakukan oleh siswa dalam kelompokkelompok tertentu untuk mencapai tujuan pembelajaran yang telah dirumuskan. ${ }^{20}$ Strategi ini mengacu pada metode pembelajaran, yang mana siswa bekerja bersama dalam kelompok kecil saling membantu dalam belajar. Adapun kelemahannya memerlukan alokasi waktu yang relatif lebih banyak. Sedangkan kelebihannya peserta didik dapat mengembangkan aktivitas, kreativitas, kemandirian, sikap kritis, dan kemampuan berkomunikasi dengan orang lain. ${ }^{21}$

Untuk itu, disetiap strategi pembelajaran memiliki kelemahan dan kelebihan, berhasil atau tidaknya strategi yang digunakan tergantung dengan gurunya karena guru merupakan motivator, fasilitator sehingga dapat mengontrol kegiatan belajar mengajar untuk mencapai keberhasilan yang ingin dicapai. Untuk mengetahui hasil paper ini, penulis akan menganalisis data yang sudah terkumpul dari hasil penelitian yang telah dilaksanakan dengan menggunakan instrumen pengumpulan data berupa observasi, wawancara, dan dokumentasi. Data ini kemudian dikumpulkan agar dapat menjawab

Available: $\quad$ http://jurnal.um-tapsel.ac.id.pdf. (diakses pada tanggal 02 Juli 2019)

20 Wina Sanjaya, Strategi Pembelajaran Berorientasi Standar Proses Pendidikan.., 241.

21 Jamil Suprihatiningrum, Strategi Pembelajaran, (Yogyakarta: Ar-Ruzz Media, 2016), 191-201. 
rumusan masalah serta tujuan untuk mendeskripsikan strategi pembelajaran shalat oleh guru Pendidikan Agama Islam terhadap anak tunadaksa di SDLB Negeri Pangkalpinang

\section{METODOLOGI PENELITIAN}

Penelitian yang digunakan oleh peneliti adalah penelitian kualitatif dengan menggunakan pendekatan deskriftif. Tujuan dari penelitian ini adalah untuk membuat pecandraan secara sistematis, faktual, dan akurat mengenai fakta-fakta dan sifat-sifat populasi atau daerah tertentu. ${ }^{22}$ Penelitian dilakukan di Sekolah Dasar Luar Biasa (SDLB) Negeri Pangkalpinang beralamat di Jalan Basuki Rahmat Ujung III. Kelurahan Sriwijaya, Kecamatan Girimaya Provinsi Kepulauan Bangka Belitung. Data diperoleh dengan cara mewawancarai informan utama, yaitu guru yang mengajar mata pelajaran Pendidikan Agama Islam di SDLB Negeri Pangkalpinang yang berjumlah 2 orang.

\section{HASIL DAN PEMBAHASAN}

\section{Strategi Guru Pendidikan Agama Islam dalam Pembelajaran Shalat Pada Anak Tunadaksa}

Guru adalah tokoh sentral dalam kegiatan belajar, mengajar, karena tanpa seorang guru dalam pelaksanaan kegiatan belajar mengajar di sekolah, maka tujuan pendidikan dan pengajaran tidak akan berjalan dengan benar. Karena kegiatan belajar mengajar merupakan inti dari kegiatan

22 Sumadi Suryabarata, Metodologi Penelitian, (Jakarta: PT Raja Grafindo Persada, 2014), 75.

${ }^{23}$ Suryosubroto, Proses Belajar Mengajar di Sekolah, (Jakarta: Rineka Cipta, 2009), 2. pendidikan di sekolah. Dalam kegiatan belajar mengajar, tugas guru tidak hanya berperan sebagai seorang pendidik dan pengajar. Akan tetapi guru juga harus memiliki peran yang bermacam-macam, sehingga benarbenar mampu membimbing atau mempengaruhi karakteristik peserta didik. $^{23}$

Sebelum materi pelajaran disampaikan kepada siswa, guru harus memahami dan menguasai bahan atau materi pelajaran yang akan diajarkan kepada peserta didik dan bahan pelajaran yang mendukung jalannya kegiatan belajar mengajar. Strategi merupakan serangkaian urutan, cara dan tindakan guru ataupun pendidik yang digunakan dalam proses belajar mengajar untuk mengoptimalkan kegiatan belajar mengajar dengan menggunakan berbagai metode pembelajaran untuk mencapai tujuan pembelajaran yang sudah diprogramkan dapat tercapai dengan baik. Untuk itu tugas dan tanggung jawab guru untuk mengajarkan normanorma pada anak didik, agar mereka tahu mana perbuatan yang baik dan mana perbuatan yang buruk. Semua norma itu tidak mesti diberi atau diajarkan di dalam kelas tetapi di luar kelas pun harus dicontohkan dengan sikap, tingkah laku atau perbuatan. ${ }^{24}$

Proses belajar mengajar yang baik adalah jika anak berinteraksi dengan pendidik. Karena itu, pendidik harus pandai menciptakan suasana yang nyaman, membangkitkan semangat belajar, antusias, dan memberikan strategi pengajaran yang tepat untuk anak. Strategi pembelajaran menenkankan kepada bagaimana

24 Jamal Ma'mur Asmani, Manajemen Strategi Pendidikan Anak Usia Dini, (Jakarta: Diva Press, 2009), 103. 
aktivitas guru mengajar dan aktivitas anak belajar baik dilakukan melalui pendekatan, pembiasaan, contoh , keteladanan, dan media pembelajaran. ${ }^{25}$

Strategi yang digunakan guru dalam pembelajaran shalat terhadap anak tunadaksa adalah dengan cara pembelajaran yang maksimal dengan menggunakan berbagai metode dan alat peraga apa yang telah diungkapkan oleh Ibu Isnainy dan Bapak Ovi selaku guru Pendidikan Agama Islam di SDLB Negeri Pangkalpinang. Dalam hal ini strategi pembelajaran merupakan suatu cara atau taktik yang digunakan guru untuk mencapai tujuan pembelajaran yang optimal. Strategi pembelajaran shalat yang digunakan guru Pendidikan Agama Islam terhadap anak tunadaksa di SDLB Negeri Pangkalpinang yaitu strategi ekspositori, strategi kontekstual, strategi kooperatif.

\section{Strategi Ekspositori}

Strategi yang menekankan pada proses penyampaian materi secara verbal. Artinya bertutur secara lisan dari seorang guru kepada sekelompok siswa dengan maksud agar siswa dapat menguasai materi pelajaran secara optimal. ${ }^{26}$ Adapun apa yang telah diungkapkan oleh Ibu Isnainy dan Bapak Ovi bahwa guru menyampaikan pembelajaran kepada anak tunadaksa secara verbal atau lisan dikarenakan anak tunadaksa bisa mendengar dengan baik. Jadi apa yang disampaikan oleh guru mereka bisa mendengar, sedangkan penyampaian materi kepada anak tunarungu lebih dominan dengan menggunakan bahasa isyarat.

25 Ibid..., 104.

26 Abdul Majid, Strategi Pembelajaran, (Bandung: PT Remaja Rosdakarya), 216.

${ }^{27}$ Mohamad Syarif Sumantri, Strategi Pembelajaran Teori dan Praktik di Tingkat
Di dalam dokumen direktorat tenaga kependidikan yang mengatakan bahwa pembelajaran ekspositori merupakan langkah pembelajaran yang menekankan kepada proses penyampaian materi secara verbal (lisan) dari seorang guru kepada sekelompok siswa dengan maksud agar peserta didik bisa menguasai materi pelajaran secara optimal. Dalam langkah ini materi pelajaran disampaikan langsung oleh guru. Peserta didik tidak dituntut untuk menemukan materi, karena pembelajaran ekspositori lebih menekankan kepada proses bertutur, maka sering juga di sebut dengan pembelajaran "chalk and talk". ${ }^{27}$

Dilihat dari hasil wawancara kepada guru di SDLB Negeri Pangkalpinang tentang strategi yang digunakan dalam pembelajaran shalat. Maka guru ini menggunakan strategi ekspositori. Karakteristik strategi ekspositori ini dilakukan dengan menyampaikan materi secara verbal (bertutur kata secara lisan) yang merupakan alat utama dalam melakukan strategi ini. Strategi pembelajaran ekspositori merupakan bentuk dari pendekatan pembelajaran yang berorientasi kepada guru karena guru memegang peran yang sangat dominan. Melalui strategi ini guru menyampaikan materi pembelajaran secara berstruktur dengan harapan materi pelajaran yang disampaikan itu dapat dikuasai siswa dengan baik. ${ }^{28}$ Dari apa yang diungkapkan oleh SDLB Negeri Pangkalpinang di atas, penulis menganalisis bahwa; dalam penyampaian materi shalat terhadap

Pendidikan Dasar, (Jakarta: PT Raja Grafindo Persada, 2016), 62.

28 Wina Sanjaya, Strategi Pembelajaran Berorientasi Standar Proses Pendidikan, (Jakarta: Kencana Prenada Media, 2011), 179. 
anak tunadaksa guru menyampaikan materi dengan ceramah dan menggunakan alat peraga berupa gambar tentang shalat. Alat peraga tersebut digunakan sebagai penunjang dalam proses pembelajaran agar berjalan dengan optimal.

\section{Strategi Kontekstual}

Strategi ini adalah konsep pembelajaran yang mendorong guru untuk menghubungkan materi yang diajarkan dengan situasi dunia nyata peserta didik. ${ }^{29}$ Di SDLB Negeri Pangkalpinang guru menerapkan strategi kontekstual dalam proses belajar mengajar anak Tunadaksa. Konsep belajar yang guru hubungkan antara materi yang diajarkannya dengan situasi dunia nyata peserta didik dan mendorong peserta didik untuk membuat hubungan antara pengetahuan yang dimilikinya dengan menerapkannya ke dalam kehidupan mereka sebagai anggota keluarga dan masyarakat. Peserta didik pun akan belajar dengan baik jika apa yang di pelajari terkait dengan apa yang telah di ketahui, dan dengan kegiatan yang akan terjadi di sekelilingnya sehingga pembelajaran ini lebih menekankan pada daya berfikir. ${ }^{30}$

Dalam hal ini guru menggunakan strategi kontekstual dengan menghubungkan materi shalat dengan cara membiasakan diri untuk melaksanakan shalat dhuha setiap hari. Sehingga mereka terbiasa untuk melakukan shalat. Dan guru juga bisa menilai dan melatih karakter masingmasing peserta didik dengan membiasakan dan mencontohkan mereka dalam melakukan shalat dhuha.

29 Isnu Hidayat, 50 Strategi Pembelajaran Populer, (Yogyakarta: DIVA Press, 2019), 40.

30 Hargio Santoso, Cara Memahami \& Mendidik Anak Berkebutuhan Khusus, (Yogyakarta: Gosyen Publishing, 2012), 20.

\section{Strategi Pembelajaran Koorperatif}

Rangkaian kegiatan belajar siswa dalam kelompok tertentu untuk mencapai tujuan pembelajaran yang dirumuskan. Strategi ini berfokus pada penggunaan kelompok kecil siswa untuk bekerja sama dalam memaksimalkan kondisi belajar untuk mencapai tujuan. Strategi ini juga menuntut peserta didik untuk belajar dalam sebuah tim yang akan sangat membantu perkembangan keterampilan sosial, sikap, dan kognitif. 31 adapun apa yang diungkapkan oleh guru di SDLB Negeri Pangkalpinang bahwa guru membagikan kelompok kecil dalam pembelajaran shalat, dan guru tidak hanya mengajarkan gerakannya melainkan bacaannya juga. Guru menyampaikannya dengan suara yang keras atau lantang. Dalam proses pembelajaran guru pun lebih memperbanyak menggunakan praktik ketimbang menggunakan teori Media pembelajaranpun digunakan untuk menunjang proses belajar mengajar.

Pada haikatnya, pembelajaran kooperatif sama dengan kerja kelompok. Pembelajaran kooperatif mencerminkan pandangan bahwa manusia belajar dari pengalaman mereka dan partisipasi aktif dalam kelompok kecil membantu siswa belajar keterampilan sosial. Selain itu secara bersamaan dapat mengembangkan sikap demokarasi dan keterampilan berfikir logis. ${ }^{32}$ Dalam hal ini penulis menyimpulkan bahwa guru menggunakan startegi pembelajaran kooperatif. Guru membagikan dua kelompok karena siswanya hanya sedikit. Dalam pembelajaran shalat guru

31 Isnu Hidayat, 50 Strategi Pembelajaran Populer..., hlm 42-43. 176. 
terlebih dahulu menjelaskannya kepada peserta didik, kemudian barulah guru mengajarkan praktik shalatnya dengan cara berkelompok.

\section{Kelemahan dan Kelebihan Strategi Pembelajaran Shalat pada Anak Tunadaksa di SDLB Negeri Pangkalpinang}

Adapun kelemahan dan kelebihan strategi pembelajaran ini adalah sebagai berikut:

1. Strategi Pembelajaran Ekspositori

Strategi pembelajan ini hanya dapat dilakukan terhadap siswa yang memiliki kemampuan mendengar dan menyimak secara baik. Apa yang telah diungkapkan oleh Ibu Isnainy dan Bapak Ovi kelemahan dari strategi ekspositori yang guru ungkapkan yakni penyampaian materi secara lisan hanya bisa dilakukan kepada peserta didik yang memiliki kemampuan mendengar dan menyimak secara baik. Dalam pembelajaran untuk peserta didik Tunarunggu strategi ini kurang cocok untuk digunakan karena anak tunarunggu memiliki keterbatasan dalam mendengar. Dalam hal ini penulis menganalisis bahwa kelemahan strategi ekspositori ini memang hanya bisa digunakan kepada peserta didik yang memiliki kemampuan mendengar dan menyimak secara baik. Strategi ini tidak bisa digunakan kepada peserta didik yang mengalami masalah pada pendengaran. Oleh karena itu peserta didik yang tidak bisa mendengar dengan baik perlu menggunakan strategi yang lain.
Adapun kelebihannya, guru bisa mengontrol urutan dan keluasan materi. Seperti yang diungkapkan oleh bapak Ovi adalah guru dapat mengontrol keluasan materi. Dalam hal ini dibuktikan dengan pernyataan bapak Ovi yang mengatakan beliau di dalam RPP (Rencana Pelaksanaan Pembelajaran) sudah mencangkup semuanya baik dari aspek kognitif, aspek apektif maupun aspek psikomotorik. Keluasan materi dapat guru kontrol dengan memperhatikan kecakupan materi yang akan diajarkan kepada peserta didik yang akan disesuaikan dengan kompetensi dasar (KD) yang ingin dicapai.

2. Strategi Pembelajaran Kontekstual

Kelemahan strategi ini guru lebih intensif dalam membimbing peserta didik agar mereka dapat belajar sesuai dengan tahap perkembangannya. Berdasarkan apa yang telah diungkap oleh ibu Isnainy dan bapak Ovi bahwa sudah menjadi tugas dan tanggung jawab guru dalam membimbing peserta didik. Dalam proses belajar mengajar, guru mempunyai tugas untuk membimbing belajar siswa untuk mencapai tujuan. Guru mempunyai tanggung jawab untuk melihat segala sesuatu yang terjadi di dalam kelas untuk membantu proses perkembangan siswa. Membimbing anak berkebutuhan kusus seorang guru harus ikhlas dan sabar dalam membimbing mereka, guru harus mampu mengoptimalkan perannya 
sebagai pembimbing. Seorang guru harus memiliki pemahaman tentang anak yang sedang dibimbingnya. Misalnya pemahaman tentang gaya belajar dan kebiasaan belajar serta pemahaman tentang potensi dan bakat yang dimiliki anak.

Adapun kelebihannya strategi ini pembelajaranya lebih menyenangkan dan tidak membosankan, dan guru mengajak peserta didik tunadaksa untuk belajar di luar kelas dan guru juga melakukan penataan ruangan yang berbeda seperti biasanya dengan mengatur meja dan kursi yang diubah-ubah pada setiap pembelajaranya. Hal ini dilakukan untuk meningkatkan semangat belajar peserta didik dan membuat pembelajaran mereka lebih menyenangkan sebagaimana di ungkapkan oleh bapak Ovi.

3. Strategi

Kooperatif

Kelemahan strategi ini implementasinya memerlukan waktu yang panjang. bahwa kelemahan strategi kooperatif dalam pembelajaraa pada peserta didik tunadaksa memerlukan alokasi waktu yang panjang/ dan berbeda dengan anak normal. Guru menghabiskan satu materi memerlukan empat kali pertemuan. Dalam penyampian materi guru sering mengulangulang materi. Hal ini dilakukan supaya peserta didik tunadaksa dapat mengingat kembali materi yang di sampaikan oleh guru.
Terkait dengan hal tersebut, guru harus mempersiapkan pembelajaran secara matang. Di samping itu memerlukan lebih banyak tenaga, pemikiran dan waktu.

Keberhasilan

pembelajaraan kooperatif dalam upaya mengembangkan kesadaran berkelompok memang memerlukan periode waktu yang cukup panjang. ${ }^{33}$

Sedangkan kelebihan strategi ini peserta didik dapat mengembangkan kreativitas, kemandirian, sikap kritis dari kemampuan berkomunikasi dengan orang lain. bahwa kelebihan dari strategi ini guru dapat mengembangkan kemampuan peserta didik, sejauh mana keberhasilan guru menyampaikan materi dapat dilihat dari keterampilan shalat peserta didik tunadaksa. Selain itu guru juga dapat menilai dari kebiasaan mereka ketika sudah masuk waktu shalat mereka sudah tahu bahwa sudah masuk waktu shalat, baik shalat dzuhur, shalat maghrib, dan bahkan waktu shalat dhuhapun mereka tahu sebagaimana yang diungkapkan oleh bapak Ovi.

\section{KESIMPULAN}

Strategi yang digunakan oleh guru Pendidikan Agama Islam di SDLB Negeri Pangkalpinang adalah strategi pembelajaran ekspositori, kontekstual, dan kooperatif. Dari strategi pembelajaran yang digunakan guru Pendidikan Agama Islam terdapat kelemahan dan kelebihan masingmasing. Kelemahan dari ketiga strategi ini ialah tidak bisa digunakan kepada siswa yang mengalami masalah pada pendengaran, guru lebih intensif dalam membimbing dan implementasinya memerlukan waktu yang panjang. 
Sedangkan kelebihannya yaitu guru bisa mengontrol urutan dan keluasan materi, belajar lebih menyenangkan dan tidak membosankan serta dapat mengembangkan kreativitas, kemandirian, sikap kritis, dan berkomunikasi siswa dengan orang lain.

\section{DAFTAR PUSTAKA}

Ahmadi, Abu dan Joko Tri Presetya, Strategi Belajar Mengajar, Bandung: Pustaka Setia, 2015.

Hamzah B Uno, Model PembelajaranMenciptakan Proses Belajar Mengajar yang Kreatif dan Efektif, Jakarta: Bumi Aksara, 2010.

Haqiqi, Muhammad Menrisal, dkk, "Pengaruh Mode Pembelajaran Kontekstual Tacing and Learning terhadap Hasil BelajarTeknologi Informasi dan Komunikasi”, Fakultas Keguruaan Il mu Pendidikan, Universitas Putra Indonesia Padang, (online) Available: $\quad$ http://jurnal.umtapsel.ac.id.pdf.

Hidayat, Isnu. 50 Strategi Pembelajaran Populer, Yogyakarta: DIVA Press, 2019.

Ma'mur, Jamal Asmani, Manajemen Strategi Pendidikan Anak Usia Dini, Jakarta: Diva Press, 2009.

Majid, Abdul. Strategi Pembelajaran, Bandung:PT Remaja Rosdakarya, 2015.

Mulyasana, Dedi. Pendidikan Bermutu dan Berbudaya Saing, Bandung: PT Remaja Rosdakarya Offset, 2011.

Murtie, Afin. Ensikopedi Anak Berkebutuhan Khusus, Jogyakarta: Redaksi maxima, 2016.
Nurdin, Strategi Pembelajaran Pendidikan Agama Islam Bagi Anak Tunadaksa Di Sekolah Dasar Luar Biasa (SDLB) Negeri Kota Juang Kabupaten Bireuen, Tesis, Program Pasca Sarjana Prodi Pendidikan Islam Konsentrasi Pendidikan Agama Islam IAIN Sumatra Utara, (online) available: http://repository.uinsu.ac.ai/2952 /1/tesis\%20Nurdin\%20.pdf.

Ohmae, Kenichi, Islamic Financial Management, Jakarta: PT Raja Grafindo Persada, 2010

Rinakri, Jati Atmaja, Pendidikan Dan Bimbingan Anak Berkebutuhan Khusus, Bandung: PT Remaja Rosdakarya, 2018.

Rohan, Muhammad dan Sofan Amir, Strategi dan Desain Pengembangan Sistem Pembelajaran, Jakarta: Prestasi Pustaka Publisher, 2009..

Santoso, Hargio. Cara Memahami \& Mendidik Anak Berkebutuhan Khusus, Yogyakarta: Gosyen Publishing, 2012.

Suprihatiningrum, Jamil. Strategi Pembelajaran, Yogyakarta: ArRuzz Media, 2016.

Suryabarata, Sumadi. Metodologi Penelitian, Jakarta: PT Raja Grafindo Persada, 2014.

Suryosubroto, Proses Belajar Mengajar di Sekolah, Jakarta: Rineka Cipta, 2009.

Syarif Mohamad Sumantri, Strategi Pembelajaran Teori dan Praktik di Tingkat Pendidikan Dasar, Jakarta: PT Raja Grafindo Persada, 2016. 
Undang-Undang Nomor 20 Tahun 2003 tentang Sistem Pendidikan Nasional terutama pasal 5 ayat (2)

Zein, Anisa. "Strategi Pembelajaran Pendidikan Agama Islam Pada Anak Berkebutuhan Khusus (ABK) Tunarungu di SLB ABC Taman Pendidikan Islam Medan", Skripsi Fakultas Ilmu Tarbiyah dan Keguruan UIN Sumatera Utara, Medan, 2018. 